\title{
Laboreal
}

Volume $15 \mathrm{~N}^{\circ} 1$ | 2019

Trabalho e cooperação

\section{Em busca da produtividade na mineração de carvão: uma análise dos coletivos e competências nas minúcias da atividade de operadores de minitrator}

En busca de la productividad en la minería de carbón: un análisis de los colectivos y competencias en las minucias de la actividad de operadores de minitractor

À la recherche de productivité dans les mines de charbon: analyse des collectifs et des compétences dans les moindres détails de l'activité des opérateurs de mini-tracteur

In search of productivity in coal mining: an analysis of collectives and competencies in the details of the activity of small tractor operators

Fernanda Santos Araújo, Vicente Nepomuceno e Denise Alvarez

\section{OpenEdition}

Journals

\section{Edição electrónica}

URL: http://journals.openedition.org/laboreal/1052

DOI: 10.4000/laboreal. 1052

ISSN: 1646-5237

\section{Editora}

Universidade do Porto

\section{Refêrencia eletrónica}

Fernanda Santos Araújo, Vicente Nepomuceno e Denise Alvarez, « Em busca da produtividade na mineração de carvão: uma análise dos coletivos e competências nas minúcias da atividade de operadores de minitrator », Laboreal [Online], Volume 15 N$^{0} 1$ | 2019, posto online no dia 01 julho 2019 , consultado o 10 abril 2020. URL : http://journals.openedition.org/laboreal/1052 ; DOI : https://doi.org/ 10.4000/laboreal. 1052

Este documento foi criado de forma automática no dia 10 abril 2020.

Laboreal está licenciado com uma Licença Creative Commons - Atribuição-NãoComercial 4.0 Internacional. 
Em busca da produtividade na mineração de carvão: uma análise dos coletivos e competências nas minúcias da atividade de operadores de minitrator

En busca de la productividad en la minería de carbón: un análisis de los colectivos y competencias en las minucias de la actividad de operadores de minitractor

À la recherche de productivité dans les mines de charbon: analyse des collectifs et des compétences dans les moindres détails de l'activité des opérateurs de mini-tracteur In search of productivity in coal mining: an analysis of collectives and competencies in the details of the activity of small tractor operators

Fernanda Santos Araújo, Vicente Nepomuceno e Denise Alvarez

\section{NOTA DO EDITOR}

Manuscrito recebido em dezembro/2018

Aceite após peritagem abril/2019

\section{Introdução}

Quando os pesquisadores do Instituto de Tavistock desceram para o subsolo das minas de carvão inglesas, no início do séc. XX na Inglaterra, importantes constatações 
emergiram com eles: a tecnologia eletromecânica recentemente incorporada naquele processo produtivo não era a única variável a determinar a organização do trabalho: os sistemas são sociotécnicos.

Num primeiro momento, a chegada dessa base tecnológica levou a profundas transformações nas formas de organização do trabalho, influenciando na implantação de princípios tayloristas. Entretanto, a adoção desses princípios estava levando à desestruturação dos coletivos de trabalho e, consequentemente, à perda de um valioso espaço de troca entre os trabalhadores, fundamental para a sua produtividade e saúde.

3 As minas de carvão inglesas não mostravam bons resultados com a incorporação daquela nova base tecnológica e uma experiência particular chamou a atenção dos pesquisadores. Em Chopwell, os trabalhadores conseguiram, a partir de um intenso processo de luta e negociação, implantar os grupos semi-autônomos, que organizavam coletivamente o processo produtivo. Essa conquista gerou resultados surpreendentes, tanto do ponto de vista da produção, quanto no que tange à saúde dos trabalhadores. Trist e sua equipe de pesquisa compreenderam, a partir dessa experiência, que os coletivos de trabalho desempenham um papel fundamental na busca pela produtividade (Trist \& Bamforth, 1951; Trist, Higgin, Murray, \& Pollock, 1963; Trist, 1981).

4 Em 1987, em Criciúma, pequena cidade de interior no sul do Brasil, um grupo de mineiros assumiu o controle de uma mineradora em vias de falência. Criaram uma cooperativa - a COOPERMINAS - e passaram a gerir coletivamente o empreendimento, orientados pelos princípios da autogestão.

5 O desejo por compreender e apoiar a luta pela autogestão travada por esses trabalhadores nos levou a desenvolver um projeto de assessoria na empresa em 2014/2015. O projeto intitulado Mineiros para o Estudo do Trabalho na Autogestão (META) [1] foi uma forma de pesquisa-ação, orientada pela Análise Ergonômica do trabalho (AET) (Guérin, Laville, Daniellou, Durrafourg, \& Kerguelen, 2001), voltada para regularizar o patamar de produção da mina em torno de 4.500 ton/dia - demanda apontada pelos trabalhadores da COOPERMINAS na primeira etapa da AET.

6 A intervenção realizada na cooperativa alimentou diversas questões para reflexão e pesquisa. Em outros textos refletimos sobre nossas opções metodológicas, seus erros e acertos, sobre o aspecto da formação dos trabalhadores que participaram desse processo, sobre os limites e possibilidades da luta pela autogestão no contexto em que ela foi proposta nessa experiência, entre outros temas (Araújo, 2016; Nepomuceno, 2016). Nesse artigo enfocaremos a análise sobre a atividade coletiva e sua relação com a questão da produtividade. Esse recorte emergiu com muita clareza ao longo da intervenção, pois, a nosso ver, as causas prioritárias para a irregularidade da produtividade eram a desestruturação dos coletivos de trabalho e os problemas de coordenação do trabalho coletivo. Essa situação ficou muito evidenciada em duas operações realizadas pelos operadores de minitrator, no subsolo da mina de carvão.

7 A análise que trazemos para esse artigo emerge das observações e diálogos em torno dessas duas operações que os trabalhadores responsáveis pela limpeza das rafas [2] repetiam centenas de vezes por dia: encher e descarregar a concha de um minitrator. A análise da atividade dos operadores nessas duas situações particulares de trabalho nos permitiu identificar como se estruturavam os coletivos de trabalho em um painel [3] em exploração e como os trabalhadores construíam e mobilizavam suas competências em 
atividade. Verificamos ainda que um debate de normas e valores (Schwartz \& Durrive, 2007) estava presente em pequenos gestos da operação e era determinante para a produtividade e para a saúde dos trabalhadores.

8 Portanto, o objetivo desse artigo é apresentar uma análise da atividade de operadores de um minitrator na COOPERMINAS, revelando aspectos da atividade coletiva e da elaboração e mobilização das competências, como estratégia para compreender a questão da produtividade na empresa.

9 A relação entre a atividade coletiva e a questão da produtividade já foi feita por inúmeros autores (e.g., Caroly \& Barcellini, 2016; Schwartz, 2004; Daniellou, Simard, \& Boissières, 2010; Dejours, 2012). Nossa contribuição original é mostrar essa correlação na atividade de operadores de minitrator na mineração de carvão, e, especificamente em uma mineradora de carvão que se propõe autogestionária.

10 Para isso, esse artigo está estruturado em oito sessões. Na segunda sessão apresentamos como os dados sobre a atividade dos operadores do minitrator foram coletados e construídos. Em seguida, na terceira, focamos o conceito de produtividade, a partir da compreensão da produtividade como um valor sem dimensão (Schwartz \& Durrive, 2007).

11 Na quarta faz-se uma reflexão sobre o que é um coletivo de trabalho e a importância de sua estruturação como espaço de troca entre os trabalhadores. Nesse espaço de trocas produz-se uma atividade coletiva, capaz de mobilizar um conjunto de competências individuais e coletivas.

12 Na quinta sessão apresentamos a Cooperminas e o processo de trabalho da mineração na empresa. E, em sequência, na sexta sessão, fazemos a descrição da atividade dos operadores do minitrator, que nos permitiu propor algumas recomendações de mudança que aparecem na sétima sessão, e por último, concluímos o artigo na última sessão.

\section{Trajetória metodológica do projeto meta}

13 Por intermédio de uma pesquisa-ação orientada pela AET buscamos compreender a atividade dos operadores de minitrator na COOPERMINAS. Nos inspiramos no paradigma da formação de atores em/pela análise do trabalho para/pela a ação (Teiger \& Lacomblez, 2013; Lacomblez, Teiger, \& Vasconcelos, 2014; Duarte \& Vasconcelos, 2014) para fazer uma espécie de formação para os trabalhadores e, ao mesmo tempo, buscar elementos que propiciassem uma futura transformação do trabalho para regularizar a produtividade diária da mina. Nossa elaboração metodológica também contou com aportes da ergologia, considerando seu dispositivo dinâmico de três polos (Schwartz \& Durrive, 2007) e suas formas de aplicação - entre elas os Encontros Sobre o Trabalho (EST) (Oliveira, 2007; Souza, 2009; Gomes, 2011) [ $\left.{ }^{4}\right]$.

14 Segundo as análises iniciais, a etapa do processo que restringia a produtividade na Cooperativa era a limpeza das rafas. Para realizar a limpeza das rafas, um grupo de operadores guiava um minitrator (MT), retirando o carvão detonado do fundo das galerias subterrâneas (enchendo a concha) e o despejando-o numa correia transportadora (descarregando a concha), que o levaria à superfície da mina.

15 Realizou-se uma primeira aproximação da atividade, com entrevistas e observações que definiram um pré-diagnóstico e apontaram para um conjunto de situações problemas 
que seriam aprofundadas com os operadores de MT. Para aprofundar a análise da situação, orientados pelas referências metodológicas escolhidas, realizaram-se cinco Encontros Sobre o Trabalho (EST), com cinco operadores de MT, cada um com duração aproximada de 2 horas. Os encontros foram intermediados por outras observações da atividade inspiradas pelo "Método de Análise Guiada Individual e Coletiva em Alternância" (MÁGICA) (Vasconcelos, 2008) [5].

Os encontros não só validaram o diagnóstico, como também foram uma estratégia de formação com os trabalhadores. A formação foi um espaço onde eles se confrontaram com conceitos apresentados pelos pesquisadores para compreenderem sua situação de trabalho a partir de novos olhares. Neste processo, tanto a situação de trabalho quanto os conceitos, foram mutuamente reelaborados pelos mineiros e pelos pesquisadores.

Nos primeiros encontros foram abordados alguns conceitos em Ergonomia da Atividade (I EST), saúde e segurança do trabalho (II EST) e avaliação do trabalho (III EST). No quarto e quinto encontros, trataram-se dos conceitos de competência e coletivos de trabalho, respectivamente. A escolha desses dois últimos temas foi orientada pela grande ênfase que essas questões ganharam nos primeiros encontros.

A dinâmica dos cinco ESTs foi bastante similar, iniciando-se com cerca de 15 minutos de exposição dos conceitos por parte dos pesquisadores, seguida de um segundo momento a partir das falas extraídas das entrevistas e conversas com os trabalhadores da Cooperativa, que ajudavam a dar concretude aos conceitos. Essas exposições iniciais disparavam um debate que tinha como objetivo a troca de experiências e pontos de vista entre os operadores, fazendo emergir também as situações controversas. Além de validar o pré-diagnóstico, dando lugar a um diagnóstico final da situação de trabalho, dos debates emergiram propostas de melhorias para a operação da MT na limpeza das rafas.

Essa metodologia permitiu-nos acessar alguns traços da atividade dos operadores de MT e melhor compreender aspectos da atividade coletiva e da elaboração e mobilização de competências na atividade, além de sua relação com a questão da produtividade. Vale enfatizar que não é objetivo aqui descrever a intervenção e sim, apontar como se deu a aproximação da atividade de operadores de um minitrator na COOPERMINAS, por intermédio das verbalizações explicitadas, dos diálogos construídos, das relações causais entre os fenômenos, que foram apreendidos por meio da AET realizada.

\section{A demanda construída: aspectos da produtividade}

20 A Ergonomia da Atividade (Guerin et al., 2001) frequentemente é solicitada para resolver problemas relacionados com a saúde e segurança dos trabalhadores ou questões que envolvem a qualidade e o desenvolvimento de produtos e processos. Menos frequentemente, ela é requisitada para resolver problemas de produtividade. Segundo Athayde (2016), avançar no tema produtividade é endereçar-se às condições objetivas que permitam transformações sociais mais profundas. Para tal, é preciso que a produtividade leve em consideração produzir mais com menos - menos desgaste da saúde dos trabalhadores, menos esforço, menor custo humano.

21 Schwartz (2004) também tem esse olhar para a produtividade, ao refletir sobre eficácia e eficiência: "a eficácia como grau de alcance de um objetivo, e a eficiência como economia dos insumos ou nos meios - a abordagem de eficiência, visando a minimizar 
os custos humanos de operações" (p. 47). 0 autor nos lembra que eficácia e eficiência podem ser "valores não dimensionados" ou "dimensionados" [6]. Entretanto, diferentemente, as fórmulas clássicas de produtividade consideram como recursos a serem economizados a energia, a matéria-prima, o capital, excluindo, portanto, os valores não dimensionados.

22 A produtividade pensada como um valor sem dimensão nos permite alargar a concepção do trabalho, enriquecê-la, ao considerá-la como uma entrada (input) fundamental no processo produtivo. Trata-se de compreendê-la na complexidade do trabalho, o que significa produzir mais, consumindo menos. Assim, é possível tratar as entradas como valores consumidos ou como bens consumidos, mas não apenas os bens mensuráveis - a produção deve consumir menos a saúde dos trabalhadores, seu bemestar, sua paz de espírito, sua inteligência, sua capacidade de participação. Produzir mais, ou a mesma quantidade, consumindo menos a vida humana, assim como os demais insumos da produção. Essa é a produtividade que nos interessa. Esse foi o desafio assumido no projeto META.

\section{A produtividade e suas relações com os coletivos e as competências}

23 A experiência do trabalho é inicialmente individual e permite que cada trabalhador desenvolva uma inteligência, um modo de fazer singular. $O$ trabalho, em contrapartida, é sempre coletivo, é sempre uma relação social: "o trabalho coletivo é a maneira como os operadores e operadoras irão mais ou menos cooperar de forma eficaz e eficiente em uma situação de trabalho" (Caroly \& Barcellini, 2016, p. 56). Entretanto, o conceito de trabalho coletivo é diferente do conceito de coletivo de trabalho. A existência de um trabalho coletivo não pressupõe um coletivo de trabalho. $O$ coletivo de trabalho é uma instância por onde passa a construção das estratégias operatórias comuns e na qual o trabalhador se apoia para preencher as lacunas entre o prescrito e o real. No coletivo trocam-se experiências e compartilham-se dúvidas a respeito das situações encontradas. Dessa forma, os trabalhadores conseguem tomar decisões difíceis e arriscadas. O coletivo ajuda na resolução individual de problemas e divide a responsabilidade pelos possíveis erros e acertos, fruto da inevitável "fuga" do prescrito. Por meio desse intercâmbio, a atividade coletiva gera uma competência coletiva e permite o desenvolvimento das competências individuais (Terssac, 1992).

O patrimônio coletivo comum que esses grupos mobilizam para gerir as demandas no "aqui e agora" da atividade inclui formas compartilhadas de pensar, de sentir e de agir na vida e no trabalho. De acordo com Schwartz e Durrive (2007), os coletivos representam um laço entre pessoas que compartilham valores elaborados na/pela atividade. Esse patrimônio comum inclui ainda "atalhos de comunicação": o gesto, o olhar, a postura, que muitas vezes substituem o diálogo proporcionando economia de tempo e eficácia aos coletivos. A comunicação ágil favorece a identificação de uma situação anormal e pode evitar as consequências negativas dessa anormalidade (Athayde, 1996; Daniellou et al., 2010). O coletivo exerce, então, uma função importante para a previsão, prevenção, deteç̧ão e recuperação de disfuncionamentos na organização e nos dispositivos técnicos (Figueiredo \& Athayde, 2004). 
Caroly e Barcellini (2016) propôs o conceito de atividade coletiva para explicar como ocorre na atividade a articulação entre o coletivo de trabalho e o trabalho coletivo. Para ela, "trabalho coletivo e coletivo de trabalho são os pilares da produção de uma atividade coletiva: o coletivo de trabalho favorece o desenvolvimento das competências, a aprendizagem e a preservação da saúde e um trabalho coletivo eficaz ajuda a atingir os objetivos do desempenho" (Caroly \& Barcellini, 2016, p. 61). De tal maneira que, para a autora então, a atividade coletiva não pode ser construída unicamente a partir de uma soma das diferentes atividades individuais. Ela é formada pelas idas e vindas permanentes entre a atividade do sujeito, a implementação de um trabalho coletivo e o funcionamento do coletivo de trabalho.

Dejours (2012), por sua vez, aponta alguns requisitos fundamentais para a cooperação e para a estruturação dos coletivos de trabalho. Em primeiro lugar, o autor faz uma distinção entre cooperação e coordenação no trabalho. A coordenação diz respeito, então, à prescrição de formas de interação entre os operadores e seus modos operatórios, entretanto, nem a atividade singular de cada operador pode ser prescrita, nem tampouco a interação entre elas. À coordenação (prescrita), é necessário que os trabalhadores respondam com a cooperação (efetiva). A cooperação não pode ser determinada a priori. Os trabalhadores precisam cooperar efetivamente para criar os mecanismos (mais ou menos) estabilizados de coordenação - as regras de trabalho.

A cooperação pressupõe que cada trabalhador conheça minimamente as maneiras de trabalhar de seus colegas, o que significa tornar visíveis as inteligências singulares de cada um. Entretanto, há uma dificuldade na explicitação dessa inteligência, um déficit semiótico que torna impossível colocar esse conhecimento, esse saber-fazer, em palavras. Esse é um primeiro fator que limita a visibilidade das inteligências singulares $\mathrm{e}$, consequentemente, a coesão dos coletivos. A habilidade profissional se baseia em um conhecimento corporal do processo de trabalho que é difícil de ser apreendido. Uma vez que o corpo é o primeiro implicado na experimentação das respostas ao real, é o corpo o fundamento da inteligência do trabalho.

8 O corpo inteiro - e não apenas o cérebro - constitui a sede da inteligência e da habilidade no trabalho, pois elas se formam no e pelo trabalho. São adquiridas no exercício da atividade. Essa inteligência do corpo antecipa a simbolização e é aprendida pela prática e pela experiência, por isso existe uma limitação da linguagem para expressá-la.

Há ainda presente no campo da dificuldade de explicitação dessa inteligência o desafio referente à infração das regras, pois muitas vezes, os operadores atuam na clandestinidade. Isso porque as inteligências singulares de cada trabalhador se elaboram no confronto com a situação real de trabalho, onde os procedimentos prescritos não são suficientes, e para dar conta do real, é preciso fugir do prescrito.

Outro aspecto que interage com esse é o da confiança, e que se configura no segundo requisito fundamental para a cooperação. Para que essa inteligência saia da clandestinidade e ganhe visibilidade é preciso confiança. Para cooperar os trabalhadores precisam confiar uns nos outros, e nos seus superiores, nos seus subordinados, na organização como um todo. É preciso confiar para expor sua engenhosidade, suas inseguranças, suas dúvidas, seus erros e seus acertos, o que se constitui uma das grandes dificuldades do trabalho coletivo. Para que ela ocorra, a organização deve criar, ou permitir, a existência de espaços de discussão que serão um 
locus fundamental para a elaboração coletiva das regras e para o compartilhamento dos modos de pensar, de sentir e de agir na vida e no trabalho.

Um terceiro requisito apontado pelo autor refere-se à necessidade de reconhecimento. Por intermédio do trabalho coletivo se opera uma dinâmica de contribuição e retribuição, ou dinâmica do reconhecimento. A contrapartida que um trabalhador espera da cooperação é a retribuição. Não só a retribuição material (salário), mas principalmente uma retribuição simbólica, um reconhecimento. Entretanto, o reconhecimento das contribuições individuais supõe a constatação de que a organização do trabalho prescrita é imperfeita. Assumir isso pode ser muito difícil para o corpo técnico que formula as prescrições e pode criar um clima de insegurança para toda a organização.

O autor afirma que o reconhecimento passa por duas formas de julgamento. 0 “julgamento da utilidade técnica, econômica ou social”, que tem a ver com a eficácia da ação, e, em geral, é formulado pela hierarquia da organização. Já o "julgamento da beleza" se refere à qualidade do trabalho, passando pela apreciação da habilidade, do talento e da originalidade. Esse é dado pelos pares, aqueles que conhecem e compartilham um ofício e permite que o sujeito se reconheça como parte de um coletivo. Esse julgamento permite também o reconhecimento do que o trabalhador é capaz de fazer diferente, dando sua contribuição particular, imprimindo na situação sua "marca" e afirmando sua individualidade.

33 A dinâmica do reconhecimento é fundamental não somente para a estruturação dos coletivos, mas também para garantir a mobilização subjetiva de cada individuo e permitir a construção da sua identidade.

Para compreendermos a atividade coletiva, consideramos pertinente explorar também como se mobilizam as competências nas situações de trabalho. Antipoff (2014), ressalta a importância do corpo nessa mobilização e afirma que a inteligência está na ação e na capacidade de usá-lo em situação e em tempo real [7]. A efetividade dos planos e procedimentos previamente elaborados depende do engajamento corporal do sujeito no momento do aqui e agora. Esse engajamento é o ponto crucial da competência. Dito de outra maneira: o agir em competência é o acoplamento entre o sujeito e a situação real de trabalho. Esse acoplamento, segundo Theureau (2014), é constitutivo de toda forma de conhecer e intervir sobre o mundo, uma vez que o sujeito é a sua relação com o meio, não podendo se separar dele.

Se entendemos que o meio é sempre uma incógnita, sempre infiel (Canguilhem, 2001) e que contém o inesperado e o imprevisível, percebemos a complexidade desse desafio de pensar antecipadamente a questão da competência. As situações de trabalho são marcadas pelos encontros, sempre singulares, de um ser humano permanentemente em construção com uma história igualmente viva. Portanto, não é possível definir previamente nem o que o trabalho demanda do sujeito, nem o que o sujeito é capaz de oferecer como resposta. Schwartz e Durrive (2007) destacam a dificuldade em dizer algo sobre as competências sem traí-las, pois, elas são um agir aqui e agora.

36 Assim, a noção de competência implica na abertura do debate sobre o que é requerido no trabalho para compreender o que faz uma pessoa. Schwartz e Durrive (2007) sugerem partir de três elementos fundamentais que definem dimensões da experiência humana:

(1) algo que tem a ver com a apropriação das normas antecedentes [8]; 


\section{subsolo na empresa.}

Figura 1 - Esquema simplificado do processo de extração de carvão de COOPERMINAS

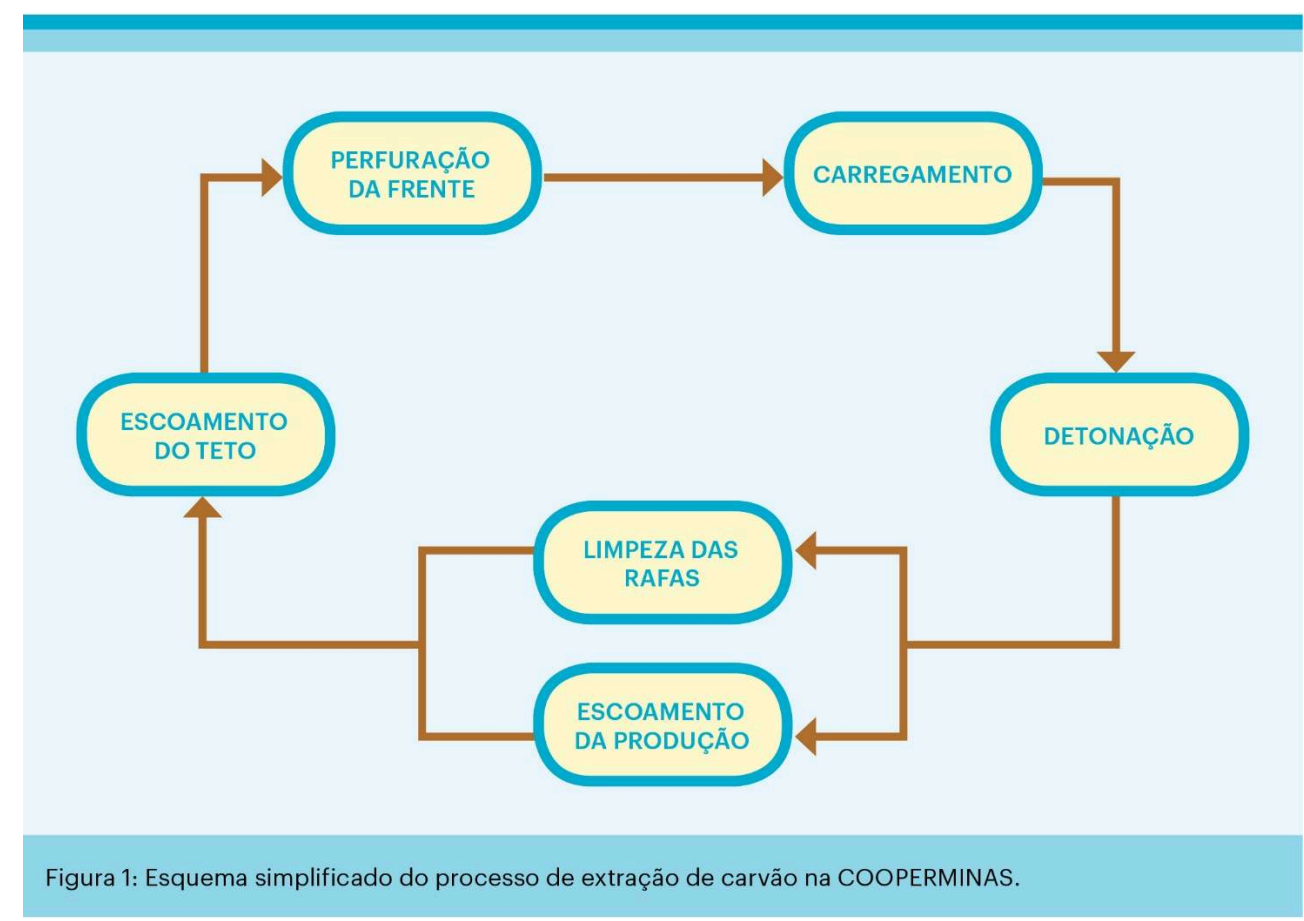

As operações que compõem esse processo formam um ciclo e são realizadas simultaneamente, por diferentes equipes de trabalho, nas diversas galerias em exploração na mina. A seguir descrevemos cada etapa da operação: 

ocupam em relação ao equipamento). No comando dessa equipe está um encarregado de produção, que conta ainda com o apoio de 1 mecânico de máquina e 1 eletricista para dar conta das demandas de manutenção que surgirem no painel. Na Figura 2 representamos um painel em operação.

51 A Figura 2 apresenta com uma linha azul a correia transportadora que atravessa o painel e se conecta em outra correia que leva o carvão para a superfície, na manutenção dessa correia estão 3 pessoas - caudeiro, cabeçoteiro e botoeira. Há ainda dois operadores de MT com seus respectivos cabistas que devem limpar o carvão detonado (indicado pelos pontos pretos) e levá-lo do fundo da galeria para a correia transportadora. 
Figura 2 - Representação esquemática da alocação da equipe de um painel em operação

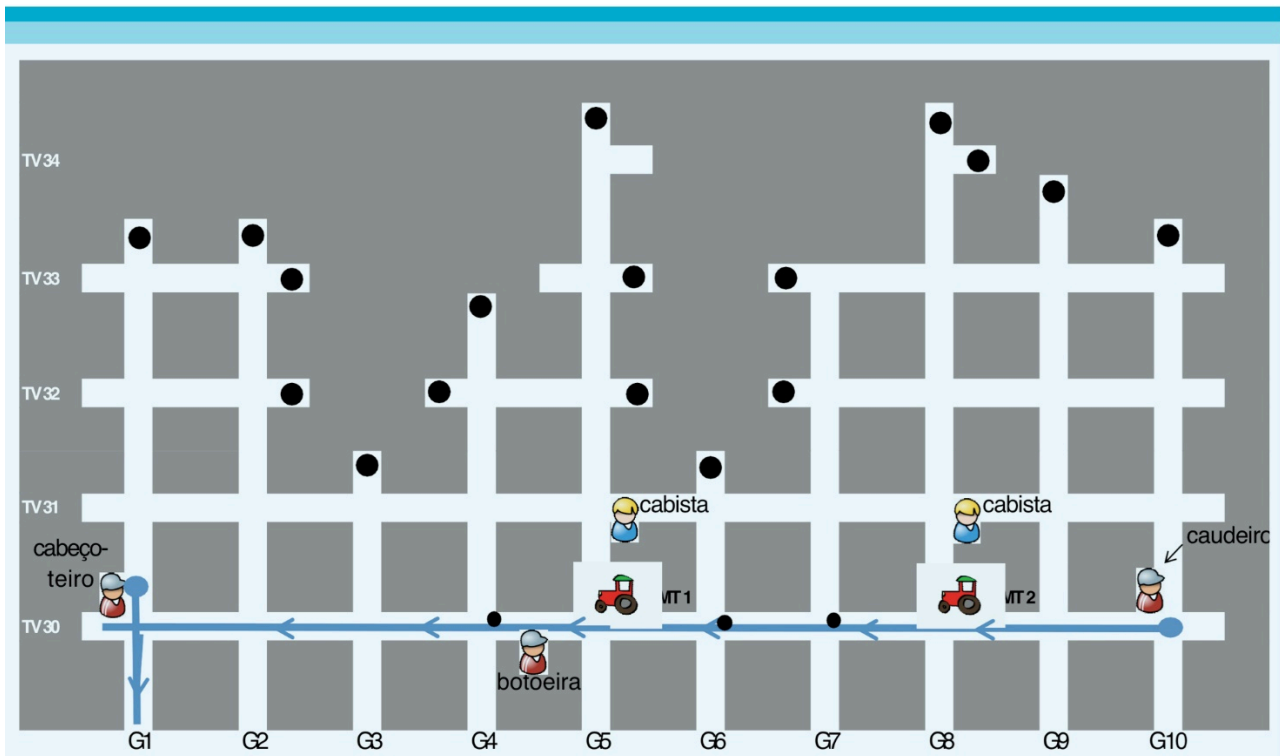

Figura 2: Representação esquemática da alocação da equipe de um painel em operação.

O ambiente e as condições de trabalho na mineração de carvão em subsolo são extremamente degradantes para a saúde e segurança dos trabalhadores. Para além das questões gerais que afetam o conjunto dos trabalhadores no subsolo, podemos destacar algumas especificidades dos riscos a que se submetem os operadores de MT.

Junto aos furadores de teto e seus ajudantes, os operadores de MT são os que estão mais expostos ao risco de desabamento de teto, pois trabalham numa região onde o teto ainda não foi escorado. São também os mais expostos à poeira, pois eles atuam justamente onde está o carvão recém-detonado, enterram as conchas de suas máquinas ali e removem o material junto com a poeira. Essa poeira, acumulada no pulmão dos indivíduos, é responsável pela pneumoconiose.

Somam-se às condições ambientais, os fatores de risco associados à máquina em operação, como a vibração, por exemplo. Segundo o engenheiro mecânico da empresa, "essa máquina não tem amortecedor, o amortecedor é a coluna do operador". A MT também produz muito calor e o acento da máquina fica bem rente ao motor, transmitindo o calor da máquina para a pessoa que trabalha. A posição da concha também representa um problema por localizar-se à frente do equipamento, e quando levantada, limita significativamente o campo de visão do operador no trajeto rafacorreia. Somando-se a isso, há barulho intenso e iluminação reduzida, fatores que dificultam a comunicação no subsolo, onde os riscos de atropelamento se tornam muito elevados. Os operadores dizem que acidentes ou quase acidentes por atropelamento acontecem toda semana. 
Figura 3 - Fotos da operação da MT na COOPERMINAS

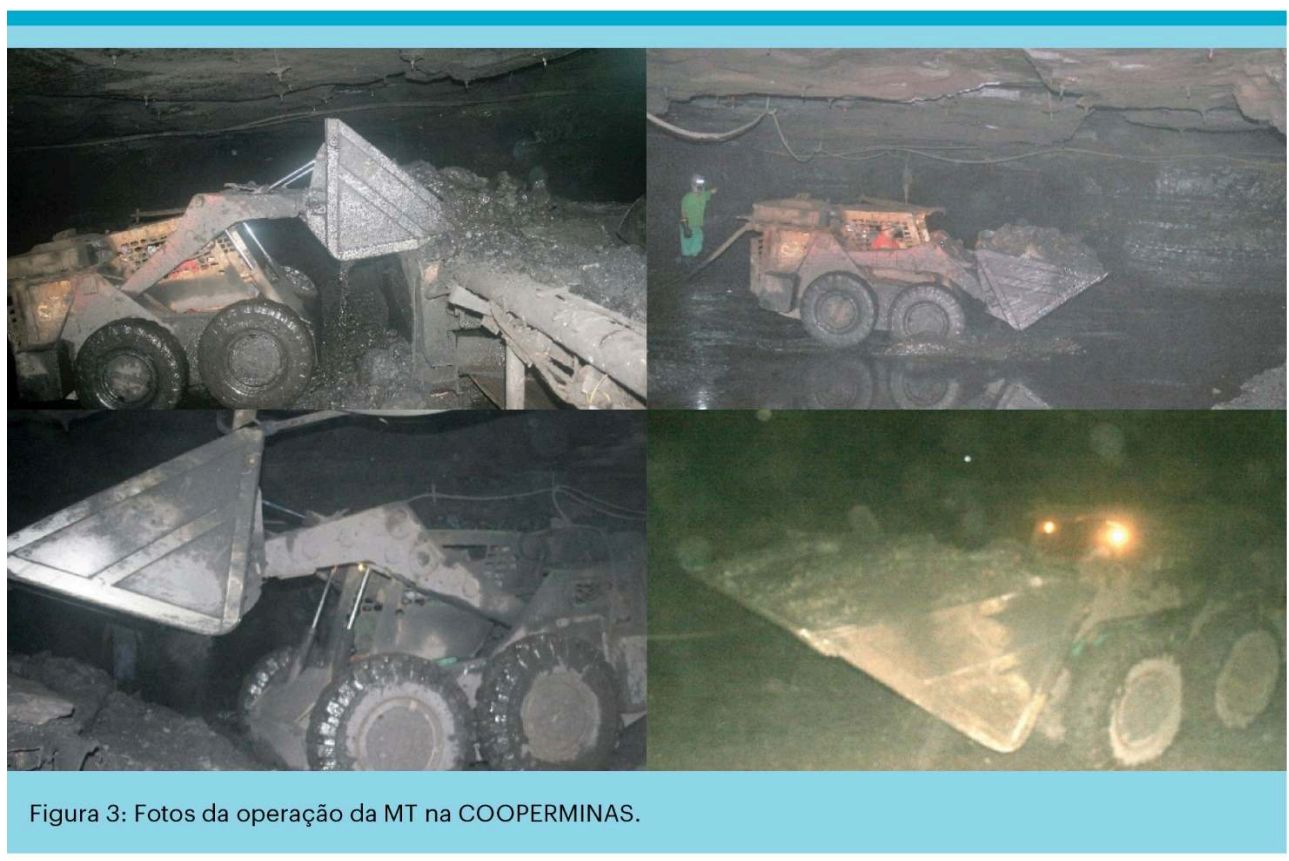

Além de gerir esses riscos presentes na atividade, os operadores de MT têm que lidar com a gestão das inúmeras variabilidades nas situações cotidianas de trabalho. Dependendo das características geológicas do solo e da qualidade das etapas anteriores do processo, a lapa (nome que se dá ao piso das galerias) pode estar mais ou menos regular, facilitando ou dificultando a atividade de limpeza das rafas. 0 tamanho das rafas também pode variar, assim como suas caraterísticas, pois a rafa pode estar mais espalhada ou mais socada, e com mais ou menos pedras. As rafas menores, mais espalhadas e com menos pedras são mais fáceis e rápidas de limpar, enquanto as maiores, mais socadas e com mais pedras são mais difíceis, demandando mais esforço do operador e do equipamento. $O$ veio do carvão também varia conforme avança a produção, há trechos em que cada detonação solta junto com o carvão pedras que não são úteis à produção. Cada operador deve separar essas pedras, principalmente as grandes, e apenas descarregar na correia o carvão com pedras pequenas. A distância entre a correia e a rafa é outra variável importante que influencia no trabalho desses operadores. Quanto mais perto a correia estiver, mais rápido e menos desgastante é o trabalho de limpar uma rafa (a correia avança conforme avança a exploração do painel). A configuração dessas variáveis pode tornar a situação mais ou menos favorável.

56 A função dos operadores de MT é, portanto, operar a máquina, recolhendo o carvão das rafas e despejando-o na correia, driblando diuturnamente essas adversidades.

\subsection{Os operadores de MT}

57 Boa parte dos trabalhadores, cerca de $50 \%$, são cooperados da empresa. Entretanto, na função de operador de MT, quase todos eram contratados, jovens (média de 32 anos), com pouco tempo na empresa (média de 2,4 anos) e com experiência anterior acumulada em outras minas da região. Trabalhavam em turnos diurno e noturno alternados semanalmente. 
58 Alguns desses trabalhadores tiveram formação para operação da máquina em outras mineradoras onde atuaram anteriormente, entretanto, boa parte de seu aprendizado foi adquirida no exercício da função. Em diversos momentos, eles ressaltaram a importância prática desse processo de formação, como se percebe nesse diálogo [ $\left.{ }^{9}\right]$ :

Lucas: Um cara pra ensinar, como é que tu vai ensinar o cara? Só se botar no colo!

[...]

Denis: Entra, conhece a máquina, conhece os pedais, dá uma voltinha, daí tem chance... bota o rapaz pra dentro da máquina com ela desligada. [...] aí o cara pegou, já ligou a máquina, olha só, só levanta a concha e cuida do cabo. Lucas: Você fica uma semana só... andando, né. Aí vai, volta, vira, vai, volta... Cláudio: Tem que ter equilíbrio. Se não tiver equilíbrio tu mata muita gente pela frente.

Esse diálogo denota a importância da experiência do corpo, que permite a educação da percepção e dos gestos. $O$ trabalhador sente a operação, processando-a cognitivamente. Muitas vezes não sabe como fez determinada manobra. E se sabe, não tem palavras para explicar, para transmitir para um outro, confirmando a deficiência das palavras para caracterizar esse saber-fazer.

O Gilberto perguntou ali pra mim, porque às vezes dá, às vezes não. Chega assim, jogou o carvão assim, na cauda. Joga o carvão assim... sai certinho o carvão. Aí ele me perguntou como é que eu fazia aquilo ali. Não sei, cara, às vezes dá, às vezes não. E é uma coisa que tu não sabe explicar pra ele como é que é. (Pedro)

Se para aprender é preciso experimentar e, quando se experimenta, "às vezes dá, às vezes não", a organização precisa ser tolerante ao erro. Permitir a experimentação, fundamental para o desenvolvimento da competência, é permitir o erro, o fracasso e o “improdutivo". É importante abrir espaço para se falar sobre a experiência, seus erros e acertos. Dejours (2012) diria que para isso é preciso confiança.

\subsection{Os operadores de correia}

61 Em forte sintonia com a limpeza das rafas, ocorre o escoamento da produção pelas correias transportadoras (CTs). Se a correia para, de nada adianta a eficiência do operador de MT. Ao mesmo tempo, na medida em que o trabalho do operador de MT é "bem feito", isso deve reduzir as paradas de correia. Os trabalhadores reclamam que a correia é muito curta e estreita e se queixam principalmente dos pontos de descarga. Essas características da correia dificultam o descarregamento e o transporte do material, tornando necessárias muitas paradas do equipamento para limpeza e manutenção.

62 A atribuição principal dos operadores de correia é mantê-la em funcionamento. Para isso, é preciso inspecionar o material que passa na esteira e, quando se identificar uma pedra grande que possa danificar o equipamento, parar a correia para retirá-la ou quebrá-la. A experiência permite identificar as pedras que podem e as que não podem passar.

63 Outra forma de manter a correia funcionando é limpando-a, isto é, retirando o material que se acumula nas partes mais sensíveis do equipamento. Quando há uma MT 
descarregando perto do local de trabalho dos operadores de correia, eles devem observar o descarregamento do material e, com uma pá, pegar o que a MT deixa cair para fora da correia e colocar de volta na esteira para o transporte.

A atividade dos operadores de correia e a dos operadores de MT deve ter uma sincronia, de maneira a permitir que o descarregamento do carvão na correia facilite a sua operação, e vice-versa. Um deve estar sempre atento aos gestos e ao posicionamento do outro, para assim regular sua atividade. Se a MT descarrega rápido demais, o operador de correia não consegue garantir a limpeza. Se a MT despeja muitas pedras, os companheiros da correia terão que parar o equipamento. Por outro lado, os operadores de correia devem se posicionar de uma forma que não atrapalhe a operação da MT.

Apesar de sua importância, para nossa surpresa, essa função não existia no plano de carreira da empresa. Não existia treinamento para operador de correia e nem instrução de trabalho para essa função. $O$ operador de correia pode ser o novato, o servente, que ainda não aprendeu uma função específica qualquer ou, ao contrário, um operador experiente. Isso pelo fato de ser considerada uma função "mais leve" (ou menos importante?), o que faz com que seja desempenhada por operadores em final de carreira que, cansados de exercer outras funções, vão "descansar" numa função mais "tranquila" [10].

Ao analisarmos o perfil dos operadores de correia verificamos diferenças significativas entre turno noturno e diurno. A análise mostrou que à noite o cargo era ocupado por apenas dois novatos contratados, frente a nove cooperados experientes em alguma função de operação. O perfil se inverte no turno diurno, onde eram seis trabalhadores contratados com menos de um ano de empresa, outros dois contratados com mais experiência, e apenas um cooperado experiente.

Os operadores de MT trabalham em turnos alternados, ficando uma semana a noite e outra de dia. Entretanto, os operadores de correia da noite, aqueles experientes que estão "descansando" numa função supostamente mais leve a espera da sua aposentadoria, não querem trocar de turno, pois recebem uma remuneração adicional pelo trabalho noturno que não querem abrir mão às vésperas da aposentadoria.

Esse descompasso gera uma grande dificuldade para o supervisor da produção na escalação das equipes de trabalho que deveria se repetir a cada semana, mas que não se consolida integralmente dado que operadores de correia não querem trocar de turno. Soma-se a isso o alto número de faltas e afastamentos dos trabalhadores. Assim, não tem sido possível manter equipes fixas nos painéis. Como consequência, constatou-se que os coletivos de trabalho compostos por operadores de MT, cabistas e operadores de correia são frequentemente desestruturados.

69 Veremos a seguir as consequências que isso acarreta para a produtividade do trabalho na limpeza das rafas.

\section{Análise da atividade na limpeza das rafas}

70 A tarefa primordial dos operadores de MT é retirar o carvão acumulado no fundo das galerias e transportá-lo até a correia. Essa operação é composta por quatro etapas principais: encher a concha de carvão nas rafas, transportar o material até a correia, descarregar o carvão e retornar para o fundo da galeria para reiniciar o ciclo. 0 ciclo de um operador de MT leva cerca de 1 minuto a 1 minuto e meio, se repetindo centenas de 
vezes a cada turno de trabalho. Vamos analisar em detalhes a primeira e a terceira etapa desse ciclo.

Figura 4 - Etapas da operação da MT (Fonte : Autor desconhecido)

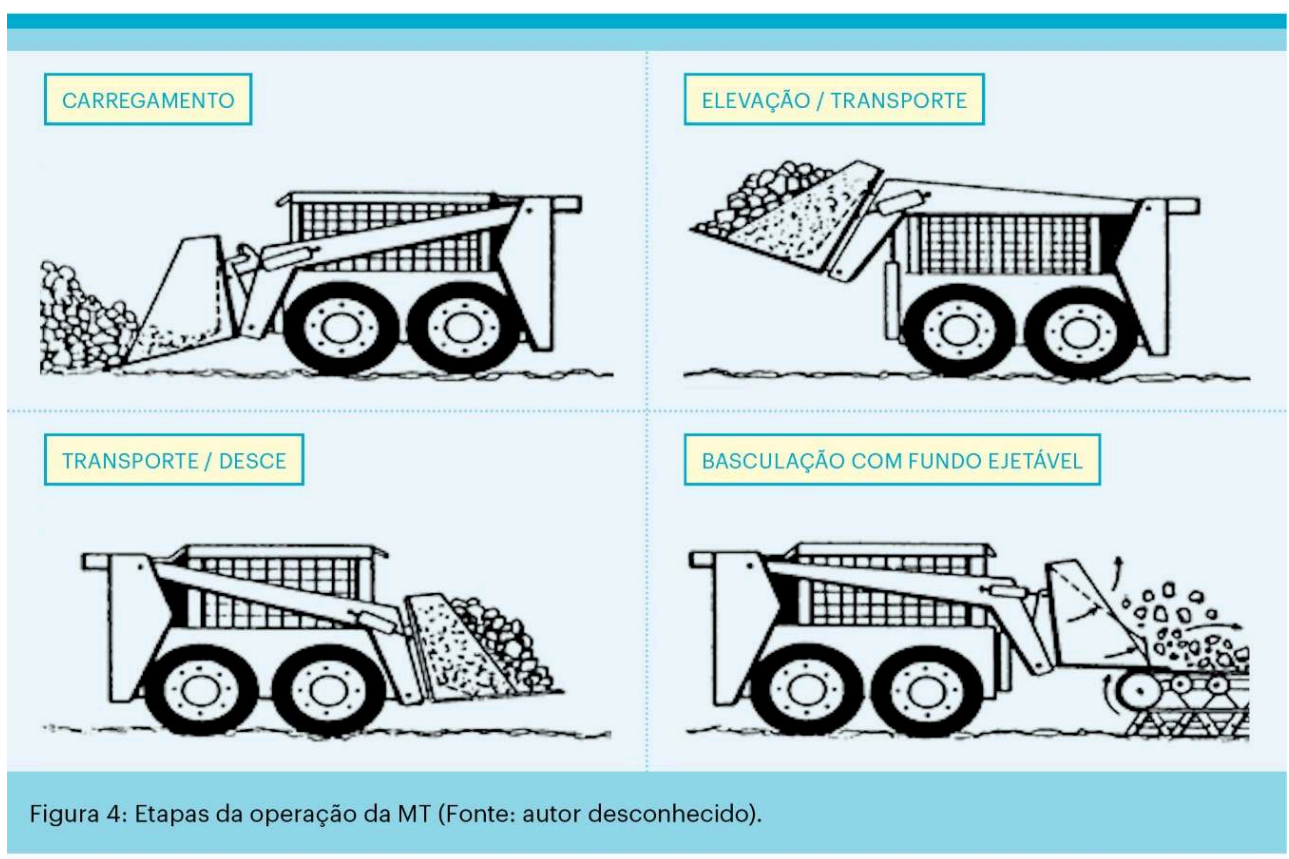

\subsection{Encher a concha}

71 A etapa de encher a concha leva cerca de 15 segundos. 0 operador repete esta operação cerca de 50 vezes por galeria ou 300 vezes por turno. Uma operação tão curta, repetitiva e mecânica traz consigo questões fundamentais para a produtividade do trabalho.

72 No momento de encher a concha o operador tem que avaliar a condição da rafa, da lapa, da máquina e seu estado de saúde para construir um modo operatório levando esses fatores em consideração. Para utilizar uma metáfora de Schwartz e Durrive (2007), ele tem que combinar os diferentes ingredientes da competência, mobilizando o conhecimento que guarda dos protocolos, deixando-se apropriar pela dimensão singular da situação e colocando em sinergia os diferentes saberes para dar conta da tarefa.

Ele precisa encher bem a concha para aproveitar melhor cada viagem e assim reduzir o número total de viagens por rafa. Se enchê-la demais, ele corre o risco de deixar parte do material cair no trajeto até a correia, desperdiçando carvão e correndo o risco de ser atingido. Quando as pedras caem na direção do cockpit da máquina, não só machucam a perna e o joelho do operador, como se acumulam perto dos pedais dificultando a operação e podendo fazer o operador perder o controle sobre ela.

Existe uma forma de ajeitar a carga para evitar que isso aconteça. Os operadores falam de "fazer uma jogadinha assim" e gesticulam para tentar explicar como fazem. Entretanto, a regra não é seguida por todos. Os colegas menos experientes, ou que "aprenderam errado", danificam a máquina na hora de encher a concha. 
“Aí o operador que fez meu café ele enterrava assim, ó, e forçava com as pedras em cima. Aí eu vi que ele já era um cara velho de mina, que não..., como é que eu vou dizer..., que não aprendeu ainda. Que quando tem uma rafa desse jeito aí, tem que tocar aqui, empinar a concha e cortar assim, ó. Cortar o carvão, pra não forçar a máquina. E tirar as pedras de cima, tirar pra trás pra depois afrouxar a rafa." (Jorge) [11] também trabalhadores experientes na mina que ainda não as desenvolveram. São os que eles chamam de operadores reservas - cabistas ou caudeiros que operam a MT quando os operadores "titulares" vão tomar seu café. Parece que esses reservas "aprenderam errado".

Lucas: É como o Jorge explicou ali, de chegar ali na frente e aliviar um pouco na tração pra deixar ela certinha, ela vai encher mais a concha e render mais. E esquentar menos.

Fernanda: Por que alguns operadores não fazem isso? Lucas: Porque já aprenderam a trabalhar daquela forma. Cláudio: E o operador que vem errado vai continuar errado. Não vai aprender. Tu pode ensinar.

No dia seguinte, Tarzan (auxiliar de Planejamento e Controle de Produção - PCP e exoperador) esclarece:

[...] são os que eram "meia boca", sempre foram "meia boca". Os que se destacavam estão saindo, saíram. Porque estavam cansados. Quem ficou no cabo ainda são aqueles que sempre foram... entendeu? São aqueles que são reserva. É esses operadores que eles falam. [...] São esses que eles dizem que aprenderam errado.

Aparentemente, o treinamento do operador no início da sua carreira, para aprender "certo", está fazendo falta. Foi curioso observar na Cooperativa que, apesar das relações de confiança na empresa parecerem bastante fragilizadas, ainda se observa alguma liberdade para se falar sobre o trabalho, sobre a atividade, seus erros e acertos, mesmo que feitas informalmente, muitas vezes fora da empresa ou fora do horário de trabalho. A organização não cria os espaços e tempos pertinentes para essa troca, nem tampouco para a experimentação dos mais jovens [ $\left.{ }^{13}\right]$.

Porém, o conhecimento da máquina e do processo e o desenvolvimento da habilidade não são os únicos requisitos para o operador conseguir fazer o movimento adequado. 
Não são só os menos experientes ou os reservas que danificam o equipamento na hora de encher a concha. Para um mesmo operador, "às vezes dá, às vezes não". Depende do seu estado atual, da situação encontrada e das suas experiências anteriores para avaliar e agir nessa situação. Em outras palavras, depende do acoplamento entre o sujeito e a situação real de trabalho, que envolve cognição, percepção e ação (Theureau, 2014).

81 Tarzan dizia que "o que faz o cara enfiar a concha no carvão forçando a tração é a ansiedade de querer produzir mais". Ele explicava que o tempo de ir e voltar do fim da galeria até a correia pouco varia, enquanto o tempo de carregar a concha é um diferencial. Logo, encher a concha mais rápido permite terminar uma rafa em menos tempo. Dessa forma, "enfiar a concha no carvão" pode levar à sensação de estar produzindo mais, o que, no entanto, pode não se efetivar ao final de um turno, pois essa atitude frequentemente faz com que a máquina pare de funcionar por superaquecimento ou outro tipo de pane antes do término da jornada. Percebe-se então que a pressão por produção determinada pela estrutura hierárquica da empresa não favorecia a prudência na operação e também prejudicava o acoplamento do sujeito com a situação, levando-o a agir de maneira contraditória, movido pela falsa sensação de estar produzindo mais.

Cumpre reforçar que a hierarquia (encarregados e supervisores) estabelece tarefas também contraditórias, hora mandando os operadores "tocar o trabalho" (produzir a qualquer custo), hora cobrando cautela e cuidado com a máquina. A fala do operador abaixo explicita essa situação.

Outra coisa: nós estamos trabalhando com as máquinas no limite. Aí essa semana eu trabalhei com uma máquina estralando lá, e se parar pra arrumar, dá um ataque no encarregado! 'Toca assim'. Toquei assim. Quebrou no final, o cubo arrebentou, a 120 arrebentou, arrebentou tudo. Queria dar advertência, punir a gente! Pô! [risos] Então, com essas situações aí, a gente precisa amadurecer nisso daí. Aí a gente assume uma responsabilidade de trabalhar com a máquina num estado terminal... e aí, tem que assumir. (Pedro)

83 A chefia cobra que os trabalhadores alcancem os resultados desejados, apesar das condições precárias. Respondendo à pressão por produção, os operadores "dão um jeitinho" desenvolvendo modos operatórios próprios que, além de degradar ainda mais o equipamento, não permitem a mesma produtividade do trabalho.

0 relato acima traz ainda à tona um problema usual na empresa: os modos operatórios necessários para suprir as lacunas entre o prescrito e o real eram tratados como fraudes e punidos com sansões. A gravidade desse ato era enfrentada com risos pelo operador, dada a poderosa estratégia de defesa desses operadores que reinventam o prazer e brincam a todos os instantes embaixo da mina. Entretanto, o ato evidencia que a hierarquia, em alguns momentos, não julga com equidade e desconsidera as variabilidades contornadas diuturnamente pelos operadores. Isso resulta numa fragilização nos laços de confiança tão importantes para estruturar os coletivos.

Esse julgamento desigual foi mais uma vez verificado quando constatamos que o operador que limpa mais rafas por turno era exaltado com frequência. Nos encontros e discussões verificou-se que todos sabiam quem foram os operadores que limparam mais na semana anterior. Em contrapartida, não era tão fácil identificar quem limpou as rafas em condições mais adversas, quem dedicou parte do seu tempo para treinar os mais jovens, quem cuidou melhor do equipamento etc. Verifica-se aí então, que é 
preciso recriar as formas de avaliar o trabalho, dando lugar a critérios de eficácia social da produção.

86 A invizibilização de determinados objetivos e valores (saúde e segurança, preservação das máquinas, planejamento da produção, entre outros) cria uma barreira, não só para a dinâmica do reconhecimento, quanto para a discussão e preservação dos valores que estão em jogo nesse tipo de empreendimento, mas também para priorizar uma visão de produtividade mais qualitativa para a saúde do coletivo e para os valores em jogo na organização.

\subsection{Descarregar o material na correia transportadora}

Uma competência fundamental do operador de MT é saber descarregar, ou despejar o material da concha na correia. Assim como encher a concha, esse é também um ato muito breve, consumindo cerca de 10 segundos do ciclo de operações. É bonito ouvir os operadores falando de um colega que sabe "tarrafear" - descarregar a concha sem parar a máquina, enquanto faz a volta. Um julgamento de beleza que permite o reconhecimento da individualidade do operador que sabe fazer desse jeito particular. Mais uma vez eles gesticulam para mostrar o movimento, explicitando o saber do corpo.

$\mathrm{Na}$ hora de descarregar, o operador de MT deve estar atento à atividade dos operadores de correia e à dos demais operadores de MT que operam no mesmo painel e descarregam na mesma correia. 0 operador do MT 1, representado na Figura 2, por exemplo, precisa observar o movimento de descarregamento do operador do MT 2, para evitar jogar o seu carvão em cima do que já foi despejado pela outra máquina. Isso sobrecarregaria a correia, levando ao transbordamento do material, que então se acumularia nas engrenagens da máquina prejudicando o seu funcionamento.

É preciso ainda, ao descarregar, observar a presença de pedras grandes na concha do MT e separá-las quando necessário. Essas pedras podem danificar o equipamento. Essa deveria ser uma "regra de ouro" que atendesse à preservação de um "valor comum", um "valor sem dimensão" na Cooperativa: a preservação dos equipamentos para que se alcançasse a produção. Entretanto, em um dos diálogos com os operadores de MT verificamos que não é assim.

Denis: E eu acho que tem que ser chamada a atenção dos operadores para quem bota pedra, às vezes... mas até mesmo nós ali, que temos um pouco mais de... acontece! Por causa que não vê.

Pedro: E não é porque o operador quer botar as pedras grandes. Claro que se tu ver uma pedra grande lá, tu não quer botar na correia. Porque tu sabe que se tu trancar aquela pedra ali [...]

Esse é o início de um longo debate que nos levou a entender o debate de valores e normas presente entre a necessidade de atingir as metas produtivas e limpar as rafas com rapidez e a preservação dos equipamentos (a correia) para que essa mesma produção tenha continuidade. Os operadores começam fazendo referência ao prescrito: não pode jogar pedra na correia. Dizem que quem descumpre esse prescrito deve ser punido. No entanto, na continuidade do diálogo, pouco a pouco os operadores vão admitindo que, às vezes, mesmo vendo a pedra ou suspeitando da presença dela, eles não a separam. 
Denis: [...] eu não concordo muito, eu acho que tem operador que vê a pedra e mesmo assim faz de conta que não [...] Porque perde mais tempo pra [...]

[...]

Jorge: Tem que parar a máquina, desligar, depois ligar, subir a elevação... Algumas a gente não vê. [...] Mas outras, tu vem aqui ó, tu aqui, tu olha, tu sente já que deu uma diferença na concha, [tu suspeita], mas tu não viu nada. Mas quando tu vê, vai às vezes rolar uma [pedra] grande. [risos] É verdade. Jorge: É isso, às vezes, fica tudo debaixo do carvão. Vai lá, tu junta, tu olha ali e só tá o carvão. Na hora que tu vai descarregar lá, que tu vê.

Fernanda: Quando você descarrega, você vê, não?

Jorge: Só na hora que tu tá lá em cima. Vê já ali.

Claudio: Na hora que tá na correia.

Fernanda: Na hora que ainda tá descarregando?

Claudio: Ainda tá saindo, né? Tu vê já lá, só... [confusão de vozes]

Denis: Às vezes não. Porque às vezes ela não é muito, ela cabe na concha, mas é mais grossa, aí o carvão tampa. Quando acontece o tipo de coisa que pega, às vezes vem o carvão por cima e a gente não vê. O caudeiro não vê. Só vê realmente quando vai descarregar na correia. [...]

Lucas: Ah não... quando ela tá em cima, aí não tem como o operador não ver. Se ela tá em cima, o operador vê, às vezes, vai dele querer quebrar, ou jogar pro lado, ou botar na correia porque sabe que vem um cara que vai tirar.

Denis: Mas dá, dá pro cara jogar o carvão pra... às vezes, quando eu fico meio suspeito às vezes eu paro. Às vezes não. Não vou dizer que faço sempre porque é mentira, mas acontece, de chegar, jogar um pouco do material pra ver se é pedra.

Vicente: Uma dúvida. O cara pegou, ele tá na dúvida. Na dúvida ele joga fora pra ver qual é ou ele joga na correia?

Denis: Às vezes descarrega [na correia], às vezes joga fora.

Vicente: Alguém descarrega?

Lucas: A maioria. Acho que todos.

Vicente: Descarrega na correia? Ah, tá. [confusão de vozes]

Denis: Às vezes vai da consciência da pessoa de chegar ali e... mas é raro. [confusão]

Denis: Porque vai perder um pouco de tempo e não tem a certeza.

Lucas: Aconteceu comigo ontem. Eu vou perder tempo? Não, vai, quando eu vi, foi, cabia três sentados em cima dela [da pedra]. [risos]

O prescrito é não colocar pedras grandes na correia, mas o real se revela depois de muitas conversas e observações. Afinal, não colocar pedras grandes na correia é uma prescrição que se contradiz a outra: terminar mais rápido a limpeza da rafa. A pressão temporal atravessa a atividade. Os trabalhadores não querem "perder tempo" separando as pedras.

92 Essa atitude afeta a atividade coletiva no painel. Quando o operador de MT não separa adequadamente as pedras do carvão sobra para o caudeiro a responsabilidade de parar a correia para retirar a pedra e/ou quebrá-la. 0 cuidado com a correia que deveria ser um valor compartilhado por todos recai sobre um trabalhador, que como vimos, ocupa uma função menos valorizada na empresa.

$\mathrm{O}$ operador de MT, que tem seu reconhecimento no trabalho associado ao número de rafas que ele limpa por turno, não se preocupa em cuidar de um equipamento que é fundamental para a produtividade de todo o painel. Ele coloca pedras grandes na correia "porque sabe que vem um cara que vai tirar". E quem é esse "cara que vai tirar"? 

ou formação para exercer nenhuma atividade especializada na mina. Enquanto no turno da noite, são trabalhadores já antigos na empresa, com experiência em alguma função de operação, mas em condições de saúde já degradadas pelo trabalho. Os mineiros dizem que nem todos os operadores de correia tem a mesma "oportunidade de falar" e que nem todos os operadores de MT ouvem e respeitam suas orientações.

[...] sobre o caudeiro ser novo e não poder dar bronca no operador quando botar a pedra... é errado! [...] Se botamos, o cara não fala, vai botar outra, porque ele não falou. [...] Mas aí, por causa daí, chama: “ô, cuidado aí que tá vindo muita pedra!". Coisa que eu acho que todo o caudeiro tem que ter essa oportunidade de falar, não é porque é mais novo ou mais velho, isso pra mim eu acho que... independente de ser mais novo, mais velho, eu acho que a gente tá ali pra trabalhar e pra ouvir os colegas de trabalho da gente. (Denis)

Observamos que no turno da noite acontecem menos paradas de correia. Parece que os caudeiros da noite, mais antigos e experientes, são também mais ouvidos e respeitados pelos operadores de MT, e assim acabam deixando passar menos pedras grandes. Não é só uma questão de respeito aos trabalhadores mais antigos, mas também de reconhecimento da sua experiência e competência.

Constatamos que na Cooperativa as constantes alterações na composição das equipes têm prejudicado o entrosamento entre os trabalhadores do grupo. A operação da correia é fortemente influenciada por esse fator. Operadores de correia e operadores de MT precisam se conhecer e confiar um no outro para se ajudarem e coletivamente construírem acordos sobre o que, como e onde descarregar. A relação entre esses trabalhadores é fundamental para o bom funcionamento do painel, pois o compartilhamento de saberes e valores se reverte em eficácia e qualidade para a produção e para a saúde.

\section{Recomendações finais do projeto meta}

Apesar de a descrição da intervenção realizada na empresa não ser objetivo desse artigo, parece-nos elucidativo apontar, mesmo que de forma superficial, algumas recomendações que foram construídas em conjunto com os operadores de MT, ao longo dos Encontros sobre o Trabalho. Apresentamos abaixo as principais diretrizes que organizaram uma lista de recomendações direcionadas para o problema dos coletivos e competências e que podem ser consultadas em Nepomuceno (2016).

A intervenção mostrou que a desestruturação dos coletivos era um elemento central para a irregularidade diária da produção. $O$ aumento na produtividade passaria diretamente pela reestruturação desses coletivos e pela construção de competências para lidar com as inúmeras variabilidades. Em consonância com essa premissa, emergem nas recomendações propostas relacionadas a mudanças na organização do trabalho (valorização da função de operadores de correia, estruturação das equipes de painel, rodízio de funções), formação (da equipe e do coletivo de trabalho como um todo) e no plano de carreira (valorização das diferentes funções presentes no coletivo). Essas propostas, oriundas da análise da atividade guiada pela demanda, tiveram como

Laboreal, Volume $15 \mathrm{~N}^{\circ} 1$ | 2019 
norte condutor o enfoque de produtividade que priorizamos em nossa abordagem. Assim, ao final do projeto, entre as recomendações para a empresa estavam:

- Reconhecimento e valorização da função dos operadores de correia;

- Estruturação das equipes por painel e por turno, buscando manter equipes fixas e cada vez mais entrosadas;

- Elaboração de um plano de formação integrado para toda a equipe de produção (operadores de correia, cabistas, operadores de MT e supervisores de produção);

- Formulação de uma política de rodízio de funções e de um plano de carreira adequado para o reconhecimento e valorização de cada um dessas funções, bem como para o desenvolvimento das competências coletivas.

\section{8. À guisa de conclusão} revelar:

\section{Encher a concha}

O objetivo desse artigo foi apresentar uma análise da atividade dos operadores de minitrator na COOPERMINAS, para revelar aspectos da atividade coletiva e da elaboração e mobilização das competências, como estratégia para compreender a questão da produtividade na empresa.

A Análise Ergonômica do Trabalho elaborada, influenciada pelo paradigma da formação de atores em/pela análise do trabalho para/pela a ação e pelo dispositivo dinâmico de três polos, se mostrou capaz de revelar alguns aspectos ocultos da atividade coletiva e da mobilização de competências no trabalho dos operadores de MT. A perspectiva da pesquisa-ação, de compreender-transformando, nos permitiu uma compreensão da atividade suficiente para a elaboração conjunta de recomendações para a transformação positiva da situação de trabalho em foco.

Buscou-se no projeto META regular a produtividade na empresa que, para nós significava produzir mais, ou a mesma quantidade, consumindo menos a vida humana, assim como os demais insumos da produção.

2 A revisão de literatura realizada nos permitiu compreender que a atividade coletiva pressupõe relações de confiança entre os diversos níveis da organização, assim como uma dinâmica do reconhecimento capaz de garantir a mobilização subjetiva da personalidade e da inteligência dos indivíduos. Assim, torna-se possível um acoplamento entre o sujeito e a situação real de trabalho, dando lugar a um agir em competência, onde estão presentes valores compartilhados que estruturam os coletivos.

A aproximação da atividade dos operadores de MT estudados fez ver que o coletivo de produção de um painel de exploração é composto por: dois operadores de MT cada um com seu cabista, por três operadores de correia, e um encarregado de produção com um mecânico e um eletricista. A análise da atividade dos operadores de minitrator foi dividida em duas partes - encher a concha e descarregar a concha - e nos permitiu

- Os operadores são pressionados para produzir mais e, com isso, forçam a máquina na hora de encher a concha, o que pode fazê-la quebrar. Os encarregados cobram um aumento de produção, mas a cautela, o cuidado com o equipamento parece não aparecer nas pressões e só se manifesta quando o equipamento quebra;

- espaço de aprendizado para desenvolver modos-operatórios que permitam encher a concha com rapidez sem quebrar a máquina são ínfimos e muitos novatos ou operadores reservas 
(função desempenhada pelos cabistas em geral) possuem dificuldade em realizar essa manobra; correia; de carvão. gestão coletiva da atividade.

- Os operadores de MT não devem colocar pedras na correia, devem separá-las do carvão, entretanto, pressionados pela necessidade de produção, acabam descarregando pedras na correia para os operadores de correia quebrarem. 0 cuidado com o equipamento que deveria ser de todos fica restrito à essa função. Essa atitude pode gerar muitas quebras e paradas de

- Verificamos que no turno da noite, onde os operadores de correia são funcionários mais antigos e respeitados, essas paradas se tornam menos frequentes;

- Os funcionários mais antigos da correia, não fazem o rodízio de turno e assim, as equipes de produção não se mantém fixas. A cada semana toda a equipe é modificada para garantir a posição fixa de alguns. Isso contribui para a desestruturação dos coletivos.

Esses aspectos da atividade coletiva e da mobilização de competências nos mostram uma série de dificuldades que impactam diretamente na produtividade da mineradora

07 Essa aproximação da atividade coletiva nos mostrou que a ousada experiência de gestão coletiva do empreendimento cooperativo ainda tem poucos reflexos no que tange à

Os supervisores e encarregados na Cooperativa ainda carregam as marcas da organização patronal, exercendo uma função de controle e pressão por resultados no curtíssimo prazo, sem levar em consideração os diversos fatores que influenciam na produtividade. Fazendo uso de ameaças e sanções, eles colocam em xeque as relações de confiança e deixam de reconhecer os diferentes valores em jogo na atividade.

Sob a pressão pela produção imediata e distantes do reconhecimento de seu esforço, os operadores de MT são impelidos a responder única e exclusivamente pelo seu "posto de trabalho", buscando limpar mais e mais rafas, sem se preocupar com a totalidade do ciclo de operações que compõe o processo produtivo, nem com os aspectos pertinentes à sua continuidade. Também não sobra tempo/espaço para a troca de experiências e para a formação dos mais jovens, gerando uma lacuna que limita o desenvolvimento de competências na atividade. Por fim, as dificuldades que a empresa enfrenta para manter as equipes de produção fixas no painel acentuam o problema de desestruturação dos coletivos de trabalho na mina.

10 Vale destacar, no entanto, que essa experiência de gestão coletiva na empresa tem outras faces, que não apresentamos nesse artigo. Um olhar mais amplo sobre sua organização do trabalho identificou avanços importantes no que tange, por exemplo, à distribuição dos excedentes de produção, à autonomia dos trabalhadores e ao equilíbrio de poder nas relações de trabalho [ $\left.{ }^{14}\right]$. 


\section{BIBLIOGRAFIA}

Antipoff, R. (2014). Competência prática, cognição e matemática na atividade de trabalhadores pouco escolarizados da construção civil (Tese de Doutoramento). Universidade Federal de Minas Gerais, Belo Horizonte, Brasil.

Araújo, F. (2016). Gestão do trabalho na COOPERMINAS: mobilização de competências e coletivos de trabalho na atividade dos operadores de uma mina de carvão em luta pela autogestão (Tese de Doutoramento). Universidade Federal Fluminense, Niterói, Brasil.

Athayde, M. (1996). Gestão de coletivos de trabalho e modernidade: questões para a engenharia de produção (Tese de Doutoramento). Universidade Federal do Rio de Janeiro, Rio de Janeiro, Brasil.

Athayde, M. (2016, janeiro). Sobre o texto Ergonomia e Formação de Vicente Nepomuceno. Palestra proferida no Exame de Qualificação de Vicente Nepomuceno na Universidade Federal Fluminense, Niterói, Brasil.

Canguilhem, G. (2001). Meio e normas do homem no trabalho. Pro-posições, 12, 35-36.

Caroly, S., \& Barcellini, F. (2016). O desenvolvimento da atividade coletiva. In P. Falzon (Dir.), Ergonomia Construtiva (pp. 55-73). São Paulo: Blucher.

Chatigny, C., \& Montreuil, S. (2003). Apprenticeship in a work setting: the contribution and limits of operational resources constructed by workers. Safety Science, 41, 377-391. https://doi.org/ 10.1016/S0925-7535(02)00044-9

Daniellou, F., Simard, M., \& Boissières, I. (2010). Fatores humanos e organizacionais da segurança industrial: um estado da arte. São Paulo: Fórum Acidentes do Trabalho: Análise, Prevenção e Aspectos Associados.

Dejours, C. (2012). Trabalho vivo: trabalho e emancipação. Brasília: Paralelo 15.

Duarte, S., \& Vasconcelos, R. (2014). Análise da atividade, participação e sustentabilidade da ação transformadora: reflexões a partir do Projeto Matriosca.

Laboreal, 10(1), 32-46. https://doi.org/10.15667/laborealx0114sd

Figueiredo, M., \& Athayde, M. (2004). Coletivos de trabalho e componentes subjetivos da confiabilidade em sistemas sociotécnicos complexos: considerações a partir da situação de trabalho em mergulho profundo na Bacia de Campos/RJ. In M. Figueiredo, M. Athayde, J. Brito, \& D. Alvarez (Dirs.), Labirintos do trabalho: interrogações e olhares sobre o trabalho vivo (pp. 241-276). Rio de Janeiro: DP\&A.

Gomes, L. (2011). Trabalhar em UTI neonatal: os desafios da relação de serviço e a saúde das/os técnicas/os de enfermagem (Tese de Doutoramento). Fundação Oswaldo Cruz, Rio de Janeiro, Brasil.

Guérin, F., Laville, A., Daniellou, F., Durrafourg, J., \& Kerguelen, A. (2001) Compreender o trabalho para transformá-lo: a prática da Ergonomia. São Paulo: Edgard Blucher.

Lacomblez, M., Teiger, C., \& Vasconcelos, R. (2014). A Ergonomia e o "paradigma da formação dos atores": uma parceria formadora com os protagonistas do trabalho. In P. F. Bendassolli, \& L. A. Soboll (Dirs.), Métodos de pesquisa e intervenção em Psicologia do trabalho: clínicas do trabalho (pp. 159-183). São Paulo: Editora Atlas. 
Masson, L. P., Gomes, L., \& Brito, J. (2015). Encontros sobre o trabalho: reflexões sobre o uso desta ferramenta metodológica em pesquisas em unidades de tratamento intensivo neonatais. Laboreal, 11(1), 23-38. http://dx.doi.org/10.15667/laborealxi0115lpm

Nepomuceno, V. (2016). Ergonomia e Formação: limites para formar e transformar o trabalho numa mineradora de carvão autogestionária (Tese de Doutoramento). Universidade Federal Fluminense, Niterói, Brasil.

Oliveira, S. (2007). Um olhar sobre a saúde a partir da dimensão gestionária do trabalho: contradições e ambigüidades no telemarketing (Tese de Doutoramento). Fundação Oswaldo Cruz, Rio de Janeiro, Brasil.

Schwartz, Y. (2004). Circulações, dramáticas, eficácias da atividade industriosa. Trabalho, Educação e Saúde, 2(1), 33-44. https://doi.org/10.1590/S1981-77462004000100004

Schwartz, Y. (2014). Motivações do conceito de corpo-si: corpo-si, atividade, experiência. Letras de Hoje, 49(3), 259-274. http://dx.doi.org/10.15448/1984-7726.2014.3.19102

Schwartz, Y., \& Durrive, L. (2007). Trabalho e Ergologia: conversas sobre a atividade humana. Niterói: EdUFF.

Souza, W. (2009). Gestão em saúde, uma perspectiva ergológica: com quantos gestos se faz uma gestão (Tese de Doutoramento). Universidade do Estado do Rio de Janeiro, Rio de Janeiro, Brasil.

Teiger, C., \& Lacomblez, M. (2013). (Se) Former pour transformer le travail: dynamiques de constructions d'une analyse critique du travail. Québec/Bruxelles: Presses de l'Université Laval/ European Trade Union Institute.

Telles, A. L., \& Alvarez, D. (2004). Interfaces ergonomia-ergologia: uma discussão sobre trabalho prescrito e normas antecedentes. In M. Figueiredo, M. Athayde, J. Brito, \& D. Alvarez (Dirs.), Labirintos do trabalho: interrogações e olhares sobre o trabalho vivo (pp. 63-91). Rio de Janeiro: DP\&A.

Terssac, G. (1992). Autonomie dans le travail. Paris: PUF.

Theureau, J. (2014). O curso da ação: método elementar. Ensaio de antropologia enativa e ergonomia de concepção. Belo Horizonte: Fabrefactum.

Trist, E. (1981). The evolution of socio-technical systems: a conceptual framework and an action research program. Ontario Quality of Working Life Centre, Toronto.

Trist, E., \& Bamforth, K. (1951). Some social and psychological consequences of the long-wall methods of coal getting. Human Relations, 4(1), 3-38. https://doi.org/

$10.1177 / 001872675100400101$

Trist, E., Higgin, G., Murray, H., \& Pollock, A. (1963). Organizational Choice: Capabilities of Groups at the Coal Face Under Changing Technologies: The Loss, Rediscovery \& Transformation of a Work Tradition. London: Tavistock Publications.

Vasconcelos, A., \& Muniz, H. (2017). O corpo psíquico e histórico no trabalho: corpo subjetivo e corpo-si. Estudos Contemporâneos da Subjetividade, 7(2), 319-328.

Vasconcelos, R. (2008). O papel do psicólogo do trabalho e a tripolaridade dinâmica dos processos de transformação: contributo para a promoção da segurança e saúde no trabalho (Tese de Doutoramento). Universidade do Porto, Porto, Portugal. 


\section{NOTAS}

1. O Projeto META foi criado dentro da realização de dois doutorados, com bolsas da CAPES, no Programa de Engenharia de Produção da Universidade Federal Fluminense - TPP/UFF (Nepomuceno, 2016; Araújo, 2016), sendo um dos subprojetos de pesquisa do Projeto "Ergonomia, Organização do Trabalho, Saúde e Segurança" desse Programa.

2. "Rafa" é o nome que se dá ao montante de carvão que se solta das rochas em uma galeria a cada detonação. É uma unidade de medida muito utilizada para o planejamento e controle da produção nas minas de carvão. $O$ trabalho do operador de MT é limpar essa rafa, ou esse carvão detonado, do fundo da galeria e descarregá-lo na correia para que ele suba para a superfície para ser beneficiado.

3. O subsolo da mina em exploração é dividido em frentes de trabalho onde o carvão é explorado. Essas frentes de trabalho recebem o nome de painel. Cada equipe de produção trabalha em um diferente painel.

4. Uma sistematização sobre estes estudos pode ser encontrada em Masson, Gomes e Brito (2015).

5. No MAGICA, a autoanálise individual era guiada pelo ergonomista na situação real de trabalho e era alternada com espaços de discussão em grupo, que permitia que cada um aproveitasse suas descobertas individuais e confrontasse-as com as representações de outros colegas, facilitando assim, o processo de desindividualização e proposição de melhorias (Vasconcelos, 2008).

6. Os valores dimensionados são aqueles cujos limites são conhecidos, que correspondem a medidas, a quantidades: aqueles do espaço nomeadamente ocupado pelo mercado, mas também através das avaliações, critérios e indicadores quantitativos. Por oposição, os valores não dimensionados são os do político, do "bem comum" (a saúde, a educação) num "mundo de valores", onde não há nem limitação interna clara entre eles, nem hierarquização possível (Schwartz \& Durrive, 2007).

7. Não exploramos aqui as contribuições trazidas por Schwartz, com o conceito de corpo-si, para essa importância do corpo no trabalho. Sugerimos, entretanto, algumas referências para essa discussão: Vasconcelos e Muniz (2017); e Schwartz (2014).

8. As normas antecedentes possuem ao menos três características: cristalizam de forma codificada as aquisições de inteligência, da experiência coletiva e dos poderes estabelecidos; são construções históricas; indicam valores ‘sem dimensão' ou ‘não dimensionados' (Telles \& Alvarez, 2004)

9. Os nomes aqui adotados são fictícios, para preservar a identidade dos trabalhadores que participaram da pesquisa.

10. No Brasil os mineiros aposentam-se após 15 anos de exercício profissional, dadas as condições degradantes dos ambientes de trabalho. No entanto, de acordo com a nossa observação na empresa, um operador de MT raramente consegue permanecer mais de 10 anos nessa função. Antes disso, ele começa a apresentar problemas de saúde (especialmente na coluna e pulmão) que restringem sua capacidade de operação.

11. A expressão "o operador que fez meu café", muito utilizada pelos trabalhadores, faz referência a uma pessoa que assume a máquina por um período, para permitir que o operador pare para descansar e se alimentar ao longo do turno.

12. Como dissemos anteriormente, a inteligência do corpo não foi trazida à tona na nossa pesquisa em todas as suas potencialidades. Seriam necessárias outras estratégias metodológicas para alcançar esse aprofundamento.

13. Muitas vezes, essa formação do operador "reserva" ocorre depois do fim da jornada, o que corrobora Chatigny \& Montreuil (2003), que identificam os fatores no ambiente que afetam o desenvolvimento da aprendizagem destacando os recursos espaço-temporais. Identificamos a dificuldade desses trabalhadores para construir o espaço de aprendizagem, pois para tal era preciso ficar depois do expediente para poder ensinar o outro colega. 
14. Apresentamos esse olhar no artigo intitulado "Autogestão na produção de carvão: avanços e contradições na experiência da COOPERMINAS" - no prelo.

\section{RESUMOS}

Apresentamos a análise da atividade de operadores de um minitrator em uma mineradora de carvão (auto)gerida pelos trabalhadores, com intuito de revelar aspectos da atividade coletiva e da elaboração e mobilização das competências, como estratégia para compreender a questão da produtividade na empresa. Metodologicamente, contamos com aportes da Análise Ergonômica do Trabalho, do paradigma da formação de atores em/pela análise do trabalho para/pela a ação e do dispositivo dinâmico de três polos. O referencial teórico-conceitual de análise está focado nos conceitos de coletivo e competência e nas contribuições da Psicodinâmica do Trabalho. Os resultados encontrados mostraram que a gestão coletiva do empreendimento ainda tem poucos reflexos na gestão coletiva da atividade. A desestruturação dos coletivos de trabalho, fruto da falta de confiança e reconhecimento, priorizava determinados valores mercantis e limitava o espaço para o desenvolvimento e mobilização das competências, impactando negativamente a produção e a saúde.

Se presenta el análisis de la actividad de operadores de un minitractor en una minería de carbón (auto)gestionada por los trabajadores, con el propósito de revelar aspectos de la actividad colectiva y de la elaboración y movilización de las competencias, como estrategia para comprender la cuestión de la productividad en la empresa. Metodológicamente, contamos con aportes del Análisis Ergonómico del Trabajo, del paradigma de la formación de actores en/por el análisis del trabajo para/ por la acción y del dispositivo dinámico de tres polos. El referencial teórico-conceptual del análisis está enfocado en los conceptos de colectivo y competencia y en las contribuciones de la Psicodinámica del Trabajo. Los resultados encontrados mostraron que la gestión colectiva del emprendimiento todavía tiene pocos reflejos en la gestión colectiva de la actividad. La desestructuración de los colectivos de trabajo, fruto de la falta de confianza y reconocimiento, priorizaba determinados valores mercantiles y limitaba el espacio para el desarrollo y movilización de las competencias, impactando negativamente la producción y la salud.

Nous présentons l'analyse de l'activité des opérateurs de mini-tracteur dans une mine de charbon (auto) gérée par les travailleurs, afin de révéler des aspects de l'activité collective, ainsi que l'élaboration et la mobilisation de compétences, donnant de la sorte à mieux comprendre les enjeux de la productivité dans l'entreprise. Sur le plan méthodologique, nous avons convoqué les contributions de l'analyse ergonomique du travail, du paradigme de la formation d'acteurs dans / par l'analyse du travail pour / par l'action et le dispositif dynamique à trois pôles. Le référentiel théorique et conceptuel reprend les concepts de collectif et de compétence et les apports de la Psychodynamique du travail. Les résultats ont montré que la gestion collective de l'entreprise avait encore peu d'écho dans la gestion collective de l'activité. La déstructuration des collectifs de travailleurs, due au manque de confiance et de reconnaissance, a donné la priorité à des valeurs marchandes et a limité l'espace pour le développement et la mobilisation des compétences, ayant un impact négatif à la fois sur la production et la santé. 
We present the analysis of the activity performed by a mini-LHD tractor in a coal mining selfmanaged by the workers. Our objective is, from this activity, to reveal aspects of collective activity and of the elaboration and mobilization of skills, as a strategy to understand the issue of productivity in the company. Methodologically, we have contributions from: the Ergonomic Work Analysis; The paradigm of training actors in / by the analysis of the work for / by the action; And from the dynamic device of three poles. The theoretical-conceptual framework of analysis is focused on the concepts of collective, competence and on the contributions from Psychodynamics of Work. The results showed that the collective management of the enterprise still has few reflexes in the collective management of the activity. The de-structuring of labor collectives, due to the lack of trust and recognition, prioritized certain market values and limited the space for the development and mobilization of skills, negatively impacting production and health.

\section{ÍNDICE}

Mots-clés: productivité, collective, compétences, mines de charbon, observation participative Palabras claves: productividad, colectivos, competencias, minería de carbón, observación participativa

Palavras-chave: produtividade, coletivos, competências, mineração de carvão, observação participativa

Keywords: productivity, collective, competencies, coal mining, participative observation

\section{AUTORES}

\section{FERNANDA SANTOS ARAÚJO}

Departamento de Engenharia de Produção do CEFET/RJ - UnED Nova Iguaçu; Estr. de Adrianópolis, 1317 - Vila Nossa Sra. da Conceição, Nova Iguaçu - RJ, Brasil 26041-271; fernanda.s.araujo@gmail.com

\section{VICENTE NEPOMUCENO}

Departamento de Engenharia de Produção da UNIRIO; Avenida Pasteur, 458, CCET, sala 402N, Urca, Rio de Janeiro - RJ, Brasil 22290-250; vicente.nepomuceno@gmail.com

\section{DENISE ALVAREZ}

Programa de Pós-Graduação em Engenharia de Produção na Universidade Federal Fluminense UFF; Rua Passo da Pátria, 156, sala 309, Bloco D, São Domingos, Niterói - RJ, Brasil 24210-240; alvarezdenise@id.uff.br 